\title{
Skin and Hides Selling Practices at Coastal Area of Sindh Province of Pakistan
}

\author{
Asad Ali Khaskheli* \\ Department of Animal Nutrition, Sindh Agriculture University, Tando jam, Pakistan \\ *Corresponding author: Asad Ali Khaskheli, Animal Nutrition, Sindh Agriculture University, Tando jam, Pakistan
}

ARTICLE INFO

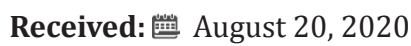

Published: 㓞 September 15, 2020

Citation: Asad Ali Khaskheli. Skin and Hides Selling Practices at Coastal Area of Sindh Province of Pakistan. Biomed J Sci \& Tech Res 30(3)-2020. BJSTR. MS.ID.004952.

Keywords: Animal Byproducts;Economic Value;Marketing;Perception;Skin Damage

\begin{abstract}
The present study was carried out to study the marketing practices of skin and hides in coastal areas of Pakistan. Results of present study indicated that in Karachi, almost $(100 \%)$ of the livestock keepers sell their hides and skins to city markets. $100 \%$ of farmer sell hides and skin to collection centers in Badin, Thatta and Sujawal. Majority of the butchers keep the animals inside house until they are slaughtered in Karachi, while at Badin and Sujawal keep the animals outside house until they are slaughtered. Most of the respondents (100\%) stated that hides and skins are important for cash income in all study areas. In all study cities, majority of respondents used freshness of hides and skins criteria during purchasing. $75.00 \%, 100 \%, 100 \%$ and $100 \%$ respectively of the respondents noticed physical defects such as absence of flay cuts for determination of bestselling price of goat skins at study areas. 50\%, 100\%, 100\% and 100\% respectively of the collection centers purchased hides and skin in the last three months from middlemen in all four areas. $100 \%$ of the collection centers had opinion that the most dominant reasons for purchasing hides and skins was low price offer in all four cities. $100 \%$ of the respondents stated that the market price varies from season to season. Most of the respondents believed that the major reason for variation in market prices of skin and hides might be due to factory/tannery price variation. In conclusion, the respondents facing many impediments in marketing of skin and hides at coastal areas of Pakistan. The major constrains faced by respondents are administrative problems, poor quality of skin and hides, storage, transportation facility, lack of handling skin and hides.
\end{abstract}

\section{Introduction}

Hide represents the 12 percentage of the value of an animal. Generally the hide is 17 percentage of the carcass weight and 7 percentage of live weight. Hence this part adds the considerable value in the animal products. The number of animals slaughtered daily clearly indicates the significant income potentiality of hides and skin, but in many parts of mountain and high-mountain, the hide is not collected at all or used inefficiently. Hide is considered just as waste material in these places. The suppliers have no or little access there due to transport difficulty.Similarly, most of the goat meat consumers prefer the skin intact meat. Public awareness along these lines is still not adequate, and the cash value of skin is ignored in many of the places. (FAO, 2010)[1]. The use of leather goes back to the pre-historic times. The principal raw material is the hide or skin of animals. Hides and skin constitute valuable material removed from the animal carcass. Skin of cow and buffalo is called hide and skin of goat and sheep is called skin. Cow and buffalo hides are 1.5-4.5 square meter in size and weigh about 15-30 kilograms (kg). Similarly, sheep and goat skins are 0.4-0.5 square meter in size and around $2 \mathrm{~kg}$ in weight. In Nepal, buffalo hide and sheep and goat skin are the byproducts of meat industry. But the cattle hide is collected from naturally died animals due to ban on cow slaughter in this country. It is estimated that bovine hides represent $12 \%$ of the value of animal. The number of animals slaughtered daily clearly indicates the significant income potentiality of hides and skin, but in many parts of mountain and high-mountain, the hide is not collected at all or used inefficiently[2] (Kagunyuet al., 2011).

Majority of the world's rural poor and a significant proportion of the urban poor keep livestock for various reasons that extend far beyond income generation (Randolph et al., 2007)[3]. Channels of hide and skin market function by four factors in which they 
are primary, secondary, tertiary and terminal. Homestead slaughterhouses based on primary markets in rural town, local collectors based on secondary markets in the cities. Livestock keepers buying their hides and skin to the primary traders in the villages and sell to wholesaler (Leach, 1995)[4]. Goat skin is considered high quality raw material for leather industry. A policy on market weight and age of slaughter may yield qualitative and quantitative leather, reduce the cost of tanning and higher value due to larger skin size. Policy is also required to generate good dividend in the market and economic return to the farmers. Presently, scanty information is available on the effect of indiscriminate marketing and slaughtering of goats on yield of hides and skins their likely impact on economy.

Therefore, an investigation is needed to formulate effective policies on rearing and marketing of goats for improving production, income of the owners as well as meet consumer's requirement. Hides and skins are the basic raw materials for the leather industry. Currently there are about 27 tanneries in the country and have an average capacity of 4,000 pieces of hides and 30,000 pieces of skins per day (EEA 2007)[5]. However, they are working under capacity even if the country has a potential to supply around 20 million pieces of hides and skins per annum. Hides and skins by-products of the livestock sector are primarily the raw material for the tanning industry; where they provide leather for the manufacture of miscellaneous leather products, but especially shoes. Although any hide or skin can be processed into leather various breeds of sheep and goats provide the overwhelming majority of raw materials. During the course of conventional (chrome) tanning, processes may be interrupted to provide intermediate materials such as pickled skins and wet blue leathers. All of these semi-processed materials, as well as raw materials and finished leathers (and leather products) may be traded internationally (FAO, 2013)[6]. Up to $65 \%$ of the defect that lead to decline of the quality occur in the pre-slaughter stage of production while the animal still alive and a considerable portion of these pre- slaughter defects are directly associated to skin disease initiated by external parasites (Desta, 2008)[7].

Limited work has been conducted on the skin and hides in the area. Information of this study may serve as a guideline for planning of proper skin removing at slaughter house, marketing channels and transportation, be care from defects scratch, and wound. Keeping in view the importance of hide and skin, the present study is designed to study skin and hide marketing practices in the coastal areas of Pakistan.

\section{Materials and Methods}

The present study was carried out during the year 2018 on the marketing of skin and hides in the coastal areas of Pakistan. Study focused 4 main cities (Karachi, Thatta, Sujawal and Badin)of coastal zone of Sindh Province of Pakistan. Initially, the general information was obtained from different sources for physical situation of the study area. Prior to collection of data, meetings were arranged with livestock experts in the cities to clear the purpose of study. Field visits were made to gather pre-information and select the villages and thereby the household.A total of 4 villages from each of 4 cities and 15 respondents form each village were selected. Respondents were interviewed to know the major management issues, constraints and causes of defect at tanneries regarding skin and hides of sheep/goat, cattle/buffalo and camel. The research was completed through a field survey by using well validated interview schedule. The interviewing schedule/questionnaire was considered an appropriate tool for the present study, which was advised according to the requirement and relevance of the present research to collect relevant data.

To attain accurate and reliable data, care and caution were taken in course of data collection. The farmers were asked questions in a face to face manner at doorstep. Based on the questionnaire the following major information was collected demographic characteristics such as educational status, purpose of keeping ruminants. 15respondents each village were selected for determining pre and post quality defects such as skin purification, wounds infestation, damages during grazing and slaughtering, knife cuts, ecto-parasites, horn rake, rope mark, small pox, branding, swelling, nodules, coloration as well as perception of respondents regarding hides and skin viz., veterinary services for sick animals, use of hide and skin, care of skin, selling of hide and skin, problems in finding buyers for sale of skin and hide, where they sale the hide and skin, constraints in sale of hides and skin in the market, marketing channels information, criteria of skin and hide buy, determination of sale prices, which type of skin and hide is highly demanded, etc.

\section{Statistical Analysis}

The data was statistically analyzed using computerized statistical package i.e. Student Edition of Statistics version 8.1. Frequency and percentage of the obtained data was worked out and are presented in the results.

\section{Results}

\section{Age Wise Distribution of the Respondents}

In Karachi, maximum number of respondents (52.38\%) were lying in the age group of 31-35 years and minimum number of respondents (4.76\%) were in the age of $15-20$ and $36-40$ years. In case of Badin 32.00\% were lying in the age group of 41-45 years and $8.00 \%$ in the age of $36-40$ years. In Thatta $28.00 \%$ were belonging to the age group of $26-30$ years and $4.00 \%$ fall in the age of $15-20$ years. However, in Sujawal the number of respondents belonging to the age group of $31-35$ years was $27.59 \%$ and to $41-45$ years was $6.90 \%$ (Figure 1). 


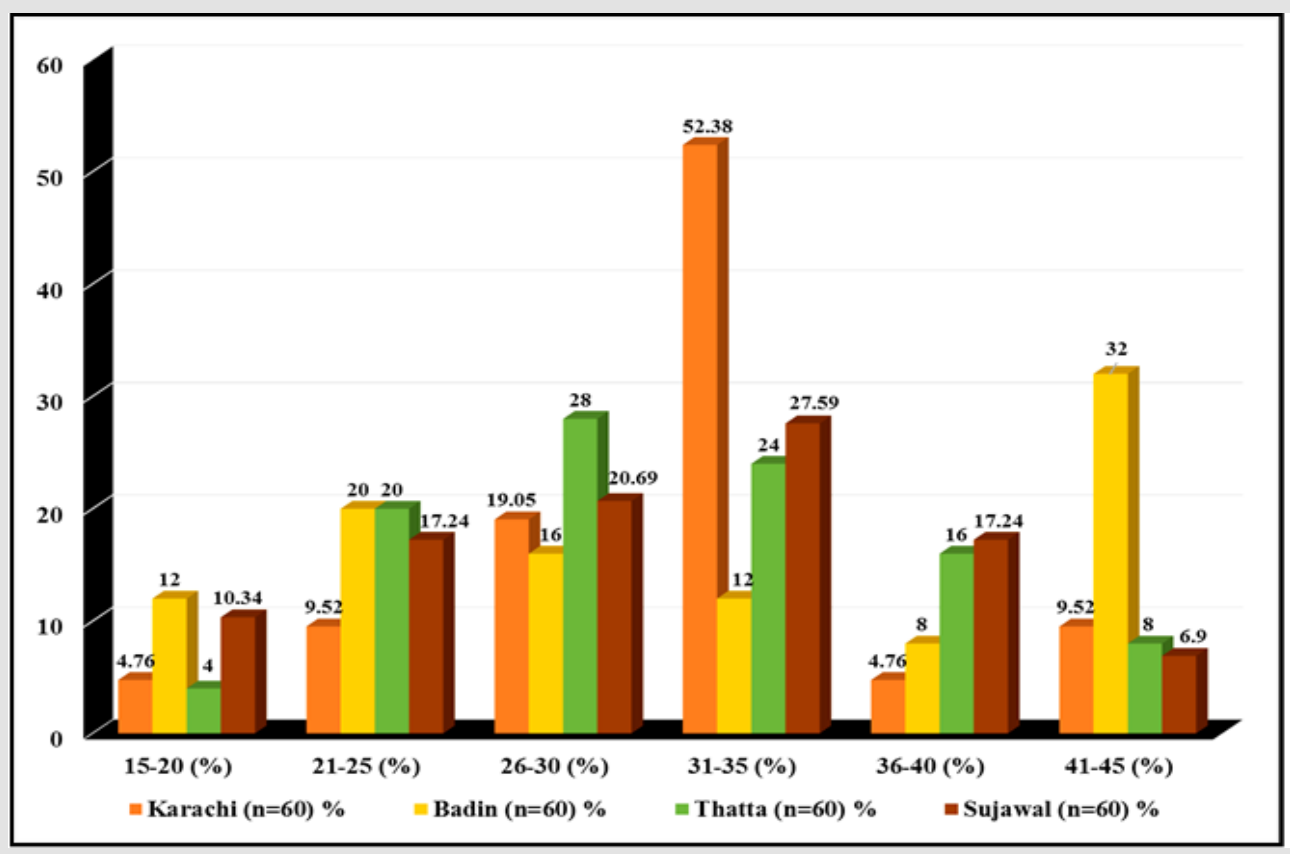

Figure 1: Age of the respondents.

\section{Educational Background of the Respondents}

Educational status of respondents in various coastal areas of Sindh Province Pakistan was evaluated and represented in the (Figure 2). Majority of the respondents (76.19\%) was intermediate, $23.81 \%$ and $4.76 \%$ were educated up to matric and middle level respectively in Karachi. In Badin, the majority (60.00\%) of respondents were educated up to matric level, $24.00 \%$ up to intermediate level and $12.00 \%$ up to middle level. In case of Thatta, maximum percentage $(64 \%)$ of the respondents was educated up to primary level, $20.00 \%$ up to middle, $12.00 \%$ up to matric and $4.00 \%$ up to intermediate level. However, in Sujawal, maximum percentage (48.28\%) of the respondents was educated up to primary level of education, $20.69 \%$ educated up to middle and matric level and $10.34 \%$ educated up to intermediate level (Figure 2).

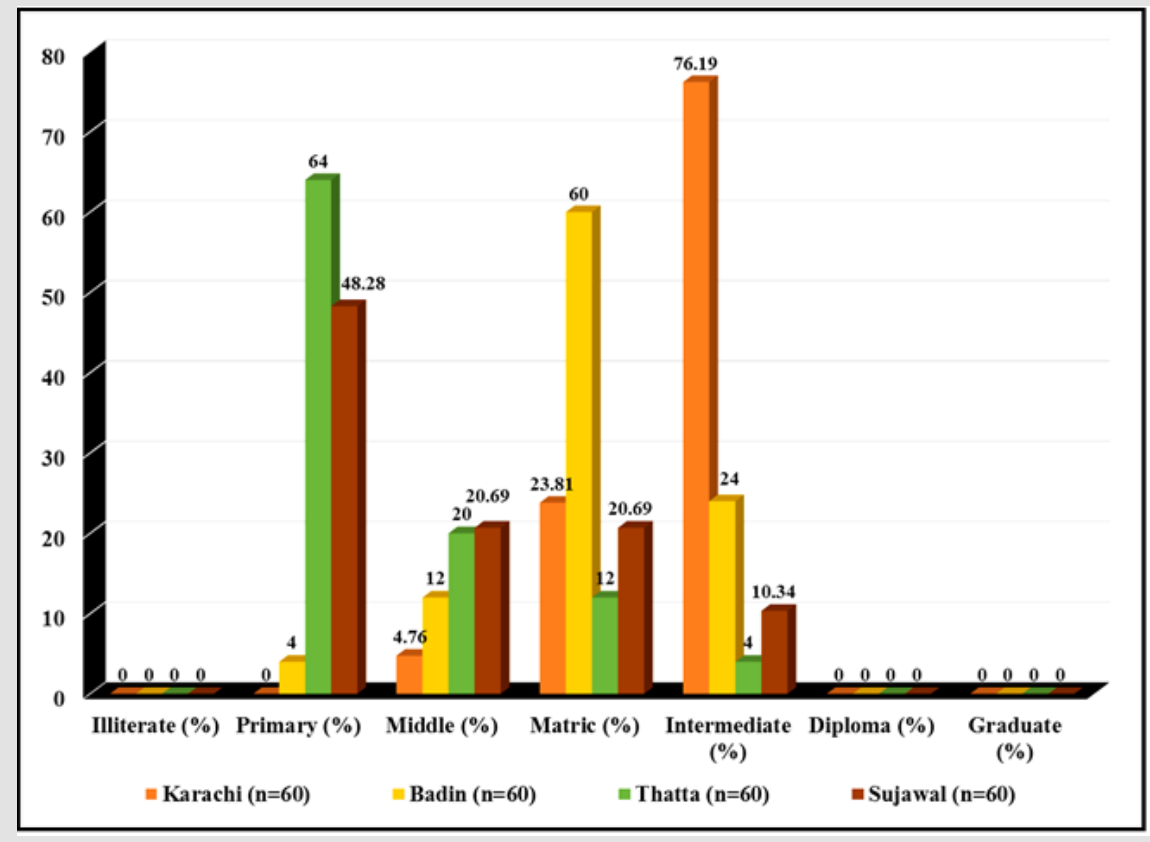

Figure 2: Education level of the respondents 
Perception of Middlemen/Traders (market) on Hides and Skin

The perception of middlemen/traders (market) regarding the hides and skin was evaluated and presented in the (Table 1). In Karachi, $100 \%$ of the livestock keepers sell their hides and skins to city market. Whereas, in Badin, Thatta and Sujawal majority $(100 \%)$ of them sell the hides and skins to the collection centers. In all four the majority $(28.57 \%, 88.89 \%, 81.82 \%$ and $76.92 \%)$ of respondents said, they face difficulty to sell and rest of the $(71.42 \%$, $11.11 \%, 18.18 \%$ and $23.08 \%$ ) of respondents said noany difficulty in finding buyers for selling. Exactly, 100\% of the respondents sell hides and skin at lower price when hides and skin were not sold, that they sold in low price in all study areas. Majority (100\%) of the respondents had opinion that the major reason of selling hides and skins was low price offer four cities. Almost $100 \%$ of the respondents stated that national price fixed the hides and skins prices in the market. Most (85.71\%, 77.78\%, 90.91\% and $84.62 \%$ ) of the respondents said no regarding look or quality of the skin when they buy and rest of the (14.29\%, 22.22\%, 9.09\% and $15.38 \%$ ) said yes for this question in all four study areas.

Table 1: Perception of middlemen / traders (market) regarding marketing of hides and skin in cities.

\begin{tabular}{|c|c|c|c|c|}
\hline \multirow{2}{*}{ P erceptions } & Karachi $(n=60)$ & Badin $(n=60)$ & Thatta $(n=60)$ & Sujawal $(n=60)$ \\
\hline & $\%$ & $\%$ & $\%$ & $\%$ \\
\hline \multicolumn{5}{|c|}{ Selling of Hides/Skins } \\
\hline To city market & 100 & 0 & 0 & 0 \\
\hline To middlemen & 0 & 0 & 0 & 0 \\
\hline To collection center & 0 & 100 & 100 & 100 \\
\hline \multicolumn{5}{|c|}{ Difficulty in Finding Buyers } \\
\hline Yes & 28.57 & 88.89 & 81.82 & 76.92 \\
\hline No & 71.42 & 11.11 & 18.18 & 23.08 \\
\hline \multicolumn{5}{|c|}{ Poor Hides / Skins Market } \\
\hline Sell at lower price & 100 & 100 & 100 & 100 \\
\hline Discard it & 0 & 0 & 0 & 0 \\
\hline \multicolumn{5}{|l|}{ Reason } \\
\hline Low price offer & 100 & 100 & 100 & 100 \\
\hline Low quality product & 0 & 0 & 0 & 0 \\
\hline \multicolumn{5}{|c|}{ Price Fixation } \\
\hline National price & 100 & 100 & 100 & 100 \\
\hline \multicolumn{5}{|c|}{ Looking Quality } \\
\hline Yes & 85.71 & 77.78 & 90.91 & 84.62 \\
\hline No & 14.29 & 22.22 & 9.09 & 15.38 \\
\hline \multicolumn{5}{|l|}{ Impact on the Price } \\
\hline Yes & 71.43 & 66.67 & 81.82 & 76.92 \\
\hline No & 28.57 & 33.33 & 18.18 & 23.08 \\
\hline \multicolumn{5}{|c|}{ Sale of Skin/Hide } \\
\hline In the same market & 100 & 100 & 100 & 100 \\
\hline To other market & 0 & 0 & 0 & 0 \\
\hline \multicolumn{5}{|l|}{ Rejection of Skin/Hide } \\
\hline Yes & 0 & 0 & 0 & 0 \\
\hline No & 100 & 100 & 100 & 100 \\
\hline \multicolumn{5}{|c|}{ Skin/Hide Defects } \\
\hline Wound & 14.29 & 33.33 & 11.11 & 33.33 \\
\hline Fly cut & 28.57 & 22.22 & 44.44 & 55.56 \\
\hline Ectoparasite & 57.14 & 44.44 & 66.67 & 55.56 \\
\hline \multicolumn{5}{|c|}{ Transport System } \\
\hline by foot & 0 & 0 & 0 & 0 \\
\hline by transport & 100 & 100 & 100 & 100 \\
\hline
\end{tabular}




\begin{tabular}{|c|c|c|c|c|}
\hline Immediate & 100 & 100 & 100 & 100 \\
\hline Later & 0 & 0 & 0 & 0 \\
\hline \multicolumn{5}{|c|}{ Preservation Method } \\
\hline Salting method & 100 & 100 & 100 & 100 \\
\hline \multicolumn{5}{|c|}{ Purpose of Skin/Hide Keeping } \\
\hline Cash income & 100 & 100 & 100 & 100 \\
\hline
\end{tabular}

Majority $(71.43 \%, 66.67 \%, 81.82 \%$ and $76.92 \%)$ of the respondents argued that look of the skin have impact on the price and remaining $(28.57 \%, 33.33 \%, 18.18 \%$ and $23.08 \%)$ of the respondents say no regarding look of the skin have impact on the price in all. Almost 100\% of the respondents sell their hides and skin in the same market in all four cities. Most (100\%) of the respondents said no regarding rejection of skin/hide when they buying in all four cities. Majority (57.14\%, 44.44\%, 66.67\% and $55.56)$ of the respondents observed ecto-parasite infestation in hides and skins, whereas $(28.57 \%, 22.22 \%, 44.44 \%$ and $55.56 \%)$ of the respondents observed fly cut defect in hides and skins at the time of buying and rest $(14.29 \%, 33.33 \%, 11.11 \%$ and $33.33 \%)$ of the respondents observed wound defect in hides and skins in all four study areas. Most of the respondents (100\%) used transport system for hides and skins in all. Almost $100 \%$ of the respondents immediately sale hides and skins after slaughtering in all four cities. $100 \%$ of the respondents used salting method for preservation of hides and skin. Most of the respondents (100\%) stated that hides and skins are important for cash income in all study areas (Table 1).

\section{Perception of Butchers on Hides and Skin}

Results in regarding the perception of butchers for marketing of hides and skin are presented in the (Table 2). In all four study areas, most $(100 \%)$ respondents buy the animals from local markets. $70.00 \%, 85.71 \%, 61.54 \%$ and $66.67 \%$ respectively of the butchers transport their animals from market to slaughter house by means of foot and rest of the $30.00 \%, 14.29 \%, 38.46 \%$ and $33.33 \%$ respectively transport their animals by means of truck in all four study regions. Majority $(80.00 \%, 78.57 \%, 92.31 \%$ and $73.33 \%$ ) of the butchers noticed some condition that could damage the skin/body of the animal along transportation route and remaining (20.00\%, 21.43\%, 7.69\% and $26.67 \%)$ did not noticed any condition that could damage the skin/body of the animal along transportation route in all.

Table 2: Perception of butchers regarding marketing of hides and skin.

\begin{tabular}{|c|c|c|c|c|}
\hline \multirow{2}{*}{ Perception } & Karachi $(n=60)$ & Badin $(n=60)$ & Thatta $(n=60)$ & Sujawal $(n=60)$ \\
\hline & $\%$ & $\%$ & $\%$ & $\%$ \\
\hline \multicolumn{5}{|c|}{ Sale of Animals } \\
\hline Local Markets & 100 & 100 & 100 & 100 \\
\hline From another markets & 0 & 0 & 0 & 0 \\
\hline \multicolumn{5}{|c|}{ Transport System } \\
\hline By foot & 70 & 85.71 & 61.54 & 66.67 \\
\hline By track & 30 & 14.29 & 38.46 & 33.33 \\
\hline \multicolumn{5}{|l|}{ Looking Quality } \\
\hline Yes & 80 & 78.57 & 92.31 & 73.33 \\
\hline No & 20 & 21.43 & 7.69 & 26.67 \\
\hline \multicolumn{5}{|c|}{ Parameters for Determining Animals Before Slaughter } \\
\hline Animal with good body condition & 60 & 78.57 & 76.92 & 73.33 \\
\hline Animal with good body condition and pure skin & 40 & 21.43 & 23.08 & 26.67 \\
\hline \multicolumn{5}{|c|}{ Looking Quality of Skin at Buying } \\
\hline Yes & 80 & 78.57 & 76.92 & 86.67 \\
\hline No & 20 & 21.43 & 23.08 & 13.33 \\
\hline \multicolumn{5}{|c|}{ Keeping of Animals } \\
\hline In house & 100 & 85.71 & 100 & 73.33 \\
\hline Outside & 0 & 14.29 & 0 & 26.67 \\
\hline \multicolumn{5}{|c|}{ Care of Skin } \\
\hline Yes & 100 & 100 & 100 & 100 \\
\hline No & 0 & 0 & 0 & 0 \\
\hline \multicolumn{5}{|c|}{ Purpose of Skin/Hide Keeping } \\
\hline Cash income & 100 & 100 & 100 & 100 \\
\hline
\end{tabular}


Almost $60.00 \%, 78.57 \%, 76.92 \%$ and $73.33 \%$ respectively of the butchers slaughter their animals due to animal with good body condition and pure skin, while $40.00 \%, 21.43 \%, 23.08 \%$ and $26.67 \%$ respectively of them slaughter due to animal with good body condition and pure skin in all study areas. Majority $(80.00 \%$, $78.57 \%, 76.92 \%$ and $86.67 \%$ ) of respondents considered the look or quality of the skin when they buy hides and skins from the market and rest $(30.00 \%, 21.43 \%, 23.08 \%$ and $13.33 \%)$ did not consider at all in four of the cities. Majority $(100 \%, 85.71 \%, 100 \%$ and $73.33 \%$ ) of the butchers keep the animals inside house until they are slaughtered in all four cities and rest of the $14.29 \%$ and $26.67 \%$ ) keep the animals outside house until they are slaughtered inBadin and Sujawal. 100\% of butchers care for the skin before slaughter in all four cities. Most of the respondents (100\%) stated that hides and skins are important for cash income.

\section{Perception of Hide and Skin Collection Centers on Hides and Skin}

The data in (Table 3)entails the information in regards to the perceptions of hide and skin collection centers for marketing of hides and skin in the coastal areas of Sindh province of Pakistan. In all 4 study areas, majority (100\%) of respondents used freshness of hides and skin as a major criteria for buying them.Majority $(75.00 \%, 100 \%, 100 \%$ and $100 \%)$ of the respondents notice physical defects such as absence of flay cuts for estimation of good selling price at all for study regions. Most $(75.00 \%, 100 \%, 100 \%$ and $100 \%$ ) of the respondents notice freshness for determination of best-selling price in all four cities. Further, 50\%, 100\%, 100\% and $100 \%$ of the collection centers purchased hides and skin in the last three months from middlemen in all four areas. $100 \%$ of collection centers salted hides and skins is highly demanded in the market in the last three months in all four regions. Most (100\%) of the collection centers stated that the hides and skins prices is fixed in the market according to the national price in all four cities. $75 \%, 100 \%, 100 \%$ and $100 \%$ of collection centers argued that they did not face any difficulty in finding buyers when they want to sell hides and skins on urgent basis in all four cities. Almost $100 \%$ of the collection centers had opinion that the most dominant reasons for purchasing hides and skins was low price offer in all four areas. Majority (100\%) of the collection centers had awareness regarding market price of hides and skins before selling-out to retailers in all four cities.

Table 3: Perception of hide and skin collection centers for marketing.

\begin{tabular}{|c|c|c|c|c|}
\hline \multirow{2}{*}{ Perception } & Karachi $(n=60)$ & Badin $(n=60)$ & Thatta $(n=60)$ & Sujawal $(n=60)$ \\
\hline & $\%$ & $\%$ & $\%$ & $\%$ \\
\hline \multicolumn{5}{|c|}{ Criteria of buy hides } \\
\hline Absence of flay defects & 0 & 0 & 0 & 0 \\
\hline Freshness & 100 & 100 & 100 & 100 \\
\hline \multicolumn{5}{|c|}{ Criteria of buy skins } \\
\hline Absence of flay defects & 0 & 0 & 0 & 0 \\
\hline Absence of pre slaughter defects & 0 & 0 & 0 & 0 \\
\hline Freshness & 100 & 100 & 100 & 100 \\
\hline \multicolumn{5}{|c|}{ Parameter for selling price for goat skin } \\
\hline Absence of defects such as flay cuts & 25 & 0 & 0 & 0 \\
\hline Freshness of the skin & 75 & 100 & 100 & 100 \\
\hline \multicolumn{5}{|c|}{ Parameter for selling price for sheep hide } \\
\hline Absence of defects such as flay cuts & 25 & 0 & 0 & 0 \\
\hline Absence of defects such as skin lesions and brands & 0 & 0 & 0 & 0 \\
\hline Freshness of the skin & 75 & 100 & 100 & 100 \\
\hline \multicolumn{5}{|c|}{ Purchasing of Hides \& Skins } \\
\hline Middlemen & 50 & 100 & 100 & 100 \\
\hline Butcheries & 50 & 0 & 0 & 0 \\
\hline \multicolumn{5}{|c|}{ Demand of skin/hide } \\
\hline Salted & 100 & 100 & 100 & 100 \\
\hline \multicolumn{5}{|c|}{ Price fixation } \\
\hline National price & 100 & 100 & 100 & 100 \\
\hline \multicolumn{5}{|c|}{ Difficulty in purchasing of skin/hide } \\
\hline Yes & 25 & 0 & 0 & 0 \\
\hline No & 75 & 100 & 100 & 100 \\
\hline
\end{tabular}




\begin{tabular}{|c|c|c|c|c|}
\hline \multicolumn{5}{|c|}{ Reason } \\
\hline Lack of price information & 0 & 0 & 0 & 0 \\
\hline Low price offer & 100 & 100 & 100 & 100 \\
\hline Low quality product & 0 & 0 & 0 & 0 \\
\hline \multicolumn{5}{|c|}{ Market price selling hides and skins } \\
\hline Yes & 100 & 100 & 100 & 100 \\
\hline No & 0 & 0 & 0 & 0 \\
\hline \multicolumn{5}{|c|}{ Price information of hides and skins in the market } \\
\hline Broker & 50 & 100 & 100 & 100 \\
\hline Other Hides and Skins traders & 25 & 0 & 0 & 0 \\
\hline Friends/ other producer's & 25 & 0 & 0 & 0 \\
\hline \multicolumn{5}{|c|}{ Price variation of hides $\&$ skins } \\
\hline Yes & 100 & 100 & 100 & 100 \\
\hline No & 0 & 0 & 0 & 0 \\
\hline \multicolumn{5}{|c|}{ Reason } \\
\hline Export price variation & 0 & 0 & 0 & 0 \\
\hline Factory/Tannery price variation /setting & 100 & 100 & 100 & 100 \\
\hline Wholesalers price setting & 0 & 0 & 0 & 0 \\
\hline \multicolumn{5}{|c|}{ High price variation } \\
\hline During holidays & 100 & 100 & 100 & 100 \\
\hline Other than holidays & 0 & 0 & 0 & 0 \\
\hline
\end{tabular}

Most $50 \%, 100 \%, 100 \%$ and $100 \%$ of the collection centers get market price information of hides and skins from broker in all four areas. Almost $100 \%$ of the respondents stated that the market price varies from season to season in all four cities. Most of the $(100 \%)$ respondents believed that the major reason for variation in market prices of skin and hides from season to season might be due to factory/tannery price variation / setting. However, majority $(100 \%)$ of the collection centers stated that during holidays the price variation reaches high in the market.

\section{Discussion}

Hides and skins need to be preserved in the mean time until they reach their final place. This is because of the fact that they are easily damaged otherwise. Preservation is a partial dehydration of the skin. The use of salt or simply air drying is supposed to assist the process of dehydration. The objectives of preservation follow the natural process of decomposition and maintain the structure of the skin in the best possible condition. The preservation process starts from the moment the animal is skinned until the skin reaches the factory where it is going to be processed (Liulseged 2011) [8]. In view of the present finding, the study concluded that the respondents facing major constraints in marketing of skin and hides in all four cities. The most prominent constraints viz., diseases and parasites, fly cut, lack of veterinary service, drought, lack of competitive pricing, lack of transparent quality, lack of access to the market, respectively.

The major constrains faced by butchers were administrative problems, unstable, poor quality of skin and hides, storage (preservation of skin and hides by means of salted vs non salted), transportation facility, lack of handling skin and hides, hygienic condition and information flow regarding marketing of skin and hides. Findings of Addis, (2014) [9] demonstrated the major factor that caused rejection of skin and hide on wet blue skins and hides. Chaudhry et al. (2011) [10]studied the hide and skin markets and abattoirs of Lahore and Faisalabad and tanneries of Sheikhupura, Kasur and Sialkot. An aggregate of 21,671 skins and hides were inspected out of which 3918 skins and 600 hides were analyzed at the abattoirs of Lahore and Faisalabad, Skins 6784 and hides 1399 at hide markets and skins 8091 and hides 879 at tanneries. Out of aggregate 21,671 skins and hides, $66.12 \%$ were normal and $33.88 \%$ were having some sort of damage. The most widely recognized damages watched in general in all species contemplated were decay of skin $6.38 \%$, followed in diving order watched was lesions of wounds $4.94 \%$, old lesions of pox $4.82 \%$, flaying cuts $3.17 \%$, tick infestation $3.08 \%$, lesions caused by parasites infestation $2.45 \%$, scratches $2.33 \%$, lesions caused by chatter fly hatchlings $1.47 \%$, disintegration $1.32 \%$, charr (fibrosis) $1.28 \%$, ringworm contamination $1.10 \%$, broad ruining by manure $0.84 \%$, interminable abscesses $0.46 \%$, and lice infestation $0.17 \%$. Zenaw and Addis (2012) [11] observed $99.9 \%$ defects. Of the aggregate skins analyzed in the study $49.2 \%$ (492/1000) fresh pickled skins were turned out to be influenced with cockle. Among the 492 skins known not cockle defects $77.23 \%$ (380/492) were sheep skins and $22.76 \%$ (112/492) were goat skins.

The species particular prevalence of cockle in sheep and goats were $76 \%$ (380/500) and 22.4\% (112/500), respectively. Melkamu 
(2014) [12] evaluated the apparent defects and grading of hides and skins in Eastern Gojjam zone. From these, 74 (41.1\%) hides, 750 (33.3\%) sheep skins, 151 (31.4\%) wet salted and 88 (30.9\%) air dried goat skins were grade I; 90 (half) hides, 1380 (61.3\%) sheep, 261 (54.4\%) wet salted and 168 (58.9\%) air dried goat skins were grade II; 16 (8.9\%) hides, 120 (5.3\%) sheep skins, 67 (14\%) wet salted and 29 (10.2\%) air dried goat skin were grade III; and $1(0.2 \%)$ wet salted goat skin was grade IV. The main watched defects that downgrade the hides were messiness with a value of 142 (17.9\%), gouge mark with a value of $140(17.7 \%)$ and poor example with a value of 107 (13.5\%). Zembabaet al. (2013) [12] investigated the dissemination and extent of major defects of sheep and goat skins. Defects caused by soil and blade are observed to be the most important defects of sheep and goatskins.

The most widely recognized damages watched in general in all species contemplated were decay of skin (thin skin) 6.38\%, followed in diving order watched was lesions of wounds $4.94 \%$, old lesions of pox $4.82 \%$, flaying cuts $3.17 \%$, tick infestation $3.08 \%$, lesions caused by parasites infestation $2.45 \%$, scratches $2.33 \%$, lesions caused by chatter fly hatchlings $1.47 \%$, disintegration $1.32 \%$, charr (fibrosis) $1.28 \%$, ringworm contamination $1.10 \%$, broad ruining by manure $0.84 \%$, interminable abscesses $0.46 \%$, and Lice infestation $0.17 \%$.Melkamu (2014) evaluated the apparent defects and grading of hides and skins in Eastern Gojjam zone. From these sums, 74 (41.1\%) hides, 750 (33.3\%) sheep skins, 151 (31.4\%) wet salted and 88 (30.9\%) air dried goat skins were grade I; 90 (half) hides, 1380 (61.3\%) sheep, 261 (54.4\%) wet salted and 168 (58.9\%) air dried goat skins were grade II; 16 (8.9\%) hides, 120 (5.3\%) sheep skins, 67 (14\%) wet salted and $29(10.2 \%)$ air dried goat skin were grade III; and $1(0.2 \%)$ wet salted goat skin was grade IV. The main watched defects that downgrade the hides were messiness with a value of 142 (17.9\%), gouge mark with a value of 140 (17.7\%) and poor example with a value of 107 (13.5\%). Zembabaet al., (2013) investigated the dissemination and extent of major defects of sheep and goat skins. Defects caused by soil and blade are observed to be the most important defects of sheep and goatskins.

\section{Conclusion}

Study concludes that the respondents face various constraints in marketing of skins and hides at the coastal areas of Sindh province of Pakistan. The most prominent constraints are diseases

\section{ISSN: 2574-1241}

DOI: $10.26717 /$ BJSTR.2020.30.004952

Asad Ali Khaskheli. Biomed J Sci \& Tech Res

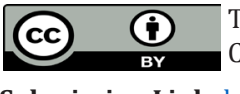

This work is licensed under Creative Commons Attribution 4.0 License

Submission Link: https://biomedres.us/submit-manuscript.php and parasites, fly cut, lack of veterinary service, drought, lack of competitive pricing, lack of transparent quality, lack of access to the market, respectively. The major constrains faced by butchers are administrative problems, unstable, poor quality of skin and hides, storage (preservation of skin and hides by means of salted vs non salted), transportation facility, lack of handling skin and hides, hygienic condition and information flow regarding marketing of skin and hides.

\section{References}

1. (2010) FAO. Study of Hide and Skin Collection and Processing. Food and Agriculture Organization of the United Nations Complex Pulchowk Nepal: 13.

2. Kagunyu A, F Wayua, E Ngari, M Lengarite (2011) Factors affecting marketing of hides and skins in pastoral communities of northern Kenya. KARI- Marsabit Technical Report.

3. Randolph TF, E Schelling, D Grace, CF Nicholson, JL Leroy, et al. (2007) Role of livestock in human and health for poverty reduction in developing countries. Journal of Animal Science 85: 2788-2800.

4. Leach IB (1995) Hides and Skins for the tanning industry agricultural service bullet in Rome, Italy.

5. (2013) FAO. World statistical compendium for raw hides and skins leather and leather footwear.

6. Desta H (2008) Common defects of sheep/goat skins in ethiopia and their technical bulletin 19: 1-11.

7. Liulseged L (2011) The performance of Hides and Skins Marketing in Gedeo Zone, Southern Nations, Nationalities and Peoples Regional State, Ethiopia.

8. Addis J (2014) Assessment of pre Slaughter Skin Management in and Around Assela and Sagure Town, East Arsi Oromia Regional State Ethiopia. DVM Thesis, Addis Ababa University, College of Veterinary Medicine and Agriculture. Department of Animal Production Studies, Bishoftu, Ethiopia: 2-20.

9. Chaudhry Z, A Saiddain, N Sabir, NA Malik, S Azeem, et al. (2011) Prevalence of pathological conditions causing skin damage and consequently reducing its market value in domestic ruminants of Punjab, Pakistan. Veterinary Science Development 1(1): 21.

10. Zenaw, Addis J (2012) Assessment of pre Slaughter Hide Management in and Around Assela and Sagure Town, East ArsiOromia Regional State Ethiopia. DVM Thesis, Addis Ababa University, College of Veterinary Medicine and Agriculture. Department of Animal Production Studies, Bishoftu, Ethiopia: 1-16.

11. Melkamu BY (2014) Apparent defects and grading of hides and skins in East Gojjam Zone, Amhara Region, Ethiopia. International Journal of Agricultural Science Research 3(11) : 232-242.

12. Zembaba B, H Ozgunay, C Vural, O Yilmaz (2013) A new defect on leather: microbial bio-film. Journal of American Leather Chemists Association 105(2): $129-134$.

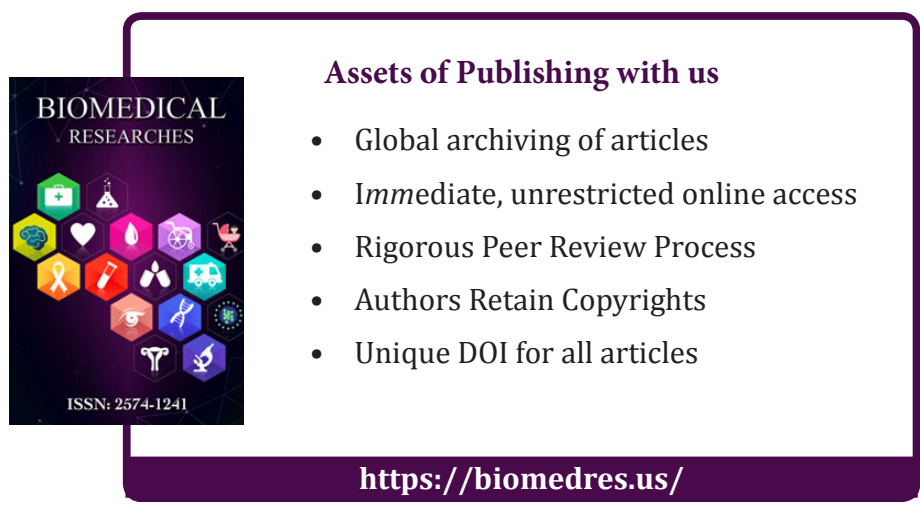

